\title{
The Individual's Influence on Low-Technology Innovation: A Critical Realism Based Case Study on North-West Pakistan's Marble Sector
}

\begin{abstract}
Muhammad Nouman ${ }^{1}$, Aamer $\mathrm{Taj}^{2}$, Saleem Gul ${ }^{3}$
Abstract

While 49 firm-level determinants of low-technology (LT) innovation have been identified through a systematic review of literature, only 9 amongst these are related to the key individual (owner and top manager). The extant literature does not shed much light on the in-depth dynamics behind presence or lack of LT innovation. Therefore, this study offers a much-needed understanding of the influence of small firm owners and managers on LT innovation in north-west Pakistan's marble industry. Advocating the need for critical realism that has been an often-ignored paradigm in management research, this paper offers a unique perspective on the paradigm's fundamental tenets which are "objects" as individuals and their roles, "mechanisms" as ways in which objects influence an event such as occurrence of LT innovation, and "causal powers" as individual-level determinants of LT innovation. A case study approach and mixed methods have been used to investigate two marble sectors. Findings reveal that the more the interests and stakes of owners and managers diverge, the lesser the instance of LT innovation. A role-ordered matrix is presented and explanations of mechanisms and causal powers are offered in terms of individuals' professional and psychological traits and nature of business stake.
\end{abstract}

Keywords: Low-technology, mixed methods, critical realism, case study

\section{Introduction}

Firms within dynamic environments characterized by technological developments have to continuously innovate in order to remain competitive (Martini, Laugen, Gastaldi \& Corso, 2013). However, how do individuals working within firms and industries with primitive technologies deal with innovation has remained an unexplored area

1 Assistant Professor, Institute of Management Sciences, Peshawar: Email: muhammad.nouman@ imsciences.edu.pk

2 Assistant Professor, Institute of Management Sciences, Peshawar: Email: aamer.taj@imsciences.edu. pk

3 Assistant Professor, Institute of Management Sciences, Peshawar: Email: s.gul@imsciences.edu.pk Accepted

ARTICLE HISTORY
\begin{tabular}{llll}
9 Nov, 2016 & Submission Received & 11 Jan, 2017 & First Review \\
\hline 20 Jan, 2017 Revised Version Received & 16 Feb, 2017 & Second Review \\
\hline 27 Feb, 2017 Revised Version Received & $10 \mathrm{Mar}, 2017$ & Accepted
\end{tabular}


(Hirsch-Kreinsen, 2008a; 2008b; Hirsch-Kreinsen \& Jacobson, 2008; Kirner, Kinker, $\&$ Jaeger, 2009). Literature on innovation has traditionally focused on two categories separately that is radical and incremental innovation (Bessant, 2008). Taking influence from innovation's incremental nature, there has been an of late increase in focus on investigating low-tech (LT) and low- and medium-tech (LMT) innovation. Influenced from OECD classification, LT sectors are characterized by having an R\&D intensity of $0-0.9 \%$, LMT 0.9 - 5\% and HT above 5\% (Hirsch-Kreinsen, 2008a). Compared to the time period 1999 - 2007 (9 publications per year on average) the number of publications on LT/LMT innovation increased twofold (16 publications) and threefold (26 publications) for 2008 and 2009 respectively suggesting an increasing trend (Nouman \& Warren, 2010). The ensuing years do not suggest a continuation of the trend. Even then this is an interesting phenomenon because compared to HT, LT is termed as the 'forgotten sector in innovation policy' (Hirsch-Kreinsen, 2008a). Evidence of a possible reviving interest in this type of innovation was the special issue of Research Policy journal on 'Innovation in Low- and Medium-Technology Industries' that was published in April 2009. The increasing attention possibly derived from growing criticism of the 'high-tech myopia' which makes us assume that economic growth results primarily from high-tech sectors and innovation in these sectors driven by R\&D (Von Tunzelmann \& Acha, 2005). Using evidence from case studies of 43 LT/LMT sectors in 9 EU countries Hirsch-Kreinsen (2008b) suggests that these sectors are mostly characterized by incremental or continuous innovation and the presence of small firms. Literature on continuous innovation has continued to evolve and incorporate a broader range of perspectives (Boer \& Gertsen, 2003). Within this context, individuals especially the owner/manager of a small firm plays a key influential role in how the firm operates. However, a detailed and systematic review of literature on LT/LMT innovation for this research spanning the last 15 years (1999 - 2014) reveals a dearth of insights on the role and influence of the individual especially owner and manager on firm-oriented LT/LMT innovation that can help us better understand continuous innovation as well.

Departing from the traditional positivist and constructivist stances the purpose of this research is to present a critical realist account of the influence of the individual (particularly the owner and manager) on LT innovation within north-west Pakistan's small marble firms. More specifically, this study has the following objectives;

- To elaborate the roles played by key individuals within marble firms in an LT sector

- To find out why or why not marble firms innovate by explaining the individual-level determinants of LT innovation 
In order to address these objectives this research study takes paradigmatic influence from critical realism (Bhaskar, 1997) and its underlying concepts. Consequently, the key individuals inside marble firms, the main focus of the study, have been conceptualized as objects or entities that are the building blocks of critical realist explanations of the world. However, these objects serve as structural components of objects at a higher level that is the LT firms and sectors (Easton, 2010). Deriving from Sayer's $(2004 ; 2000 ; 1992)$ explanations of critical realism, this research study provides a much-needed understanding of the underlying mechanisms to explain the influence of individuals on LT innovation. In this regard the focus is on causal powers of objects that refer to individual determinants of LT innovation.

\section{The Tenets of Critical Realism}

Addressing ontological and epistemological considerations underpinning any empirical work remains a priority for researchers in social sciences. This in turn underscores the importance of choosing a paradigm (Collis \& Hussey, 2003; Johnson \& Duberley, 2000; Guba \& Lincoln, 1994; Kuhn, 1970) that is at the core of a researcher's effort to generate knowledge about reality. In this regard two dominant paradigms in literature are positivism also known as empiricism, logical positivism, logical empiricism and postpositivism (Atkinson \& Hammersley, 1994; Nagel, 1986; Ayer, 1959; Popper 1959) and constructivism also known as interpretivism, phenomenology and naturalism (Schwant, 2000; Lincoln \& Guba, 1989; 1985; Glazer \& Strauss, 1977). Proponents of both paradigms are also called 'purists' (Lincoln \& Guba, 1985). Emanating from their ongoing debates that have resulted in 'paradigm wars' (Howe, 1988), is the stance of the critical realist (Bhaskar, 1997; 1989a; Collier, 1994). The fundamental tenet of critical realism is that the natural world is independent of the behaviors and actions of human beings while the social world is constructed based on the perceptions of social actors. It is for this reason that critical realists impress upon the need to differentiate between ontology and epistemology. Bhaskar (1998; 1991; 1989a) terms the lack of understanding this difference as 'epistemic fallacy' whereby one may end up mixing the nature of reality with the knowledge of reality (Johnson \& Duberley, 2000; Fairclough, 2005) Critical realists like Lawson (1997) and Sayer (2000) argue that reality is a structured open system where the 'real' includes structures with their related 'causal' mechanisms. The 'actual' includes events and processes. While the 'empirical' includes that part of the real and actual that is experienced by social actors (Fairclough, 2005).

\subsection{Acknowledging the Limitations of a Critical Realist}

It is pertinent to mention that like other paradigms, critical realists also face some queries which are not easy to address. For instance, it is difficult to determine 
whether the intransitive structures (metaphysical ontology) we construct based on our understanding are merely our imagination or real and non-empirical depiction of the actual truth (Johnson \& Duberley, 2000). In an attempt to resolve these issues Sayer (1992) presents the notion of 'thought objects' versus 'real objects'. It is argued that while there is a 'reality' external of the human mind, it is not fully comprehensible because of the limitations of human conceptualization that can only determine the structure of the world up to a certain extent only. Moreover, 'truth is neither absolute nor purely conventional and relative' (Sayer, 1992, p. 83). Bhaskar (1989b) himself implies a more realistic or pragmatic solution to the problem with 'retroduction' that focuses on explaining the structures or mechanisms underlying an ostensible phenomenon. He suggests that within the social sciences, theory and reality are causally dependent on each other. Therefore, while the society influences the formation and evolution of social theory it does not mean that the social theorist 'constructs' social reality also.

\section{Firm-Level Determinants of LT/LMT Innovation}

A sustained interest of innovation literature has been on developing a comprehensive understanding of innovation (Corso, Martini, \& Bolocco, 2008) by studying the factors influencing different kinds of innovation (Boer \& Gieskes, 2001) including firm-level determinants. Since individuals (owners/managers) are part of a firm, the literature review conducted for this paper was carried out to identify all possible determinants or factors at the firm-level (including individual-level) that influence LT/LMT innovation. The purpose was to find out what and how much do we know about the individual's influence on LT/LMT innovation compared to other firm-level factors. Additionally, the purpose was to determine what methodological approaches have been adopted by researchers. The review focused on publications between 1999 and 2014 with the idea to provide an update to our understanding of LT/LMT innovation. Kirner et al. (2009) stress the importance of studying LT/LMT innovation at the level of firm since it essentially occurs within firms. Also, from a critical realist perspective the individual is a key entity/object inside the firm with causal powers resulting in mechanisms that help explain the existence or non-existence of LT/LMT innovation amongst firms.

Determinants of innovation are influenced by a number of 'moderating conditions that include (1) firm size, (2) industrial sector the firm belongs to and (3) the environment of the country where the sector and its constituent firm exists (Souitaris, 2002; 1999). Becheikh, Landry, and Amara (2006) review empirical innovation studies on manufacturing sectors from 1993-2003 and provide a list of 'internal variables'. Apart from firm size, they identify age of firm, ownership structure, past performance, 
business strategy, organizational structure, control activities, culture, management team and functional assets. A firm's human capital developed through education, training and skill development also influences innovation (Edquist, 2005). Presenting other perspectives studies find that factors influencing innovation include innovation budget (Dunk, 2007; De Jong \& Marsili, 2006), internal R\&D, design (including ergonomics, simplified manufacturing, user friendliness and efficient material use), advanced machinery and training (Vega-Jurado, Gutierrez-Gracia, Fernandez-De-Lucio, \& Manjarres-Henriquez., 2008). Regarding design activities Filippetti (2011) finds that they are complementary to $R \& D$ activities in supporting innovation. The more a firm interacts with the external environment the greater the importance of design activities for innovation. Related to R\&D, Raymond and St-Pierre (2010) find that the influence of $R \& D$ on product innovation is mediated by process innovation for small and medium-sized firms. According to O'Regan and Kling (2011) small firms have lower $R \& D$ investment and tend to outsource it. Findings suggest that outsourcing does not bring 'inferior' results on product innovation.

Marketing and organizational innovations also add to firm's capacity to innovate. However, the influence of these innovations on firm's innovation performance (firms actually innovating and profiting from innovation) was not found (Mothe \& Thi, 2010). Evangelista and Vezzani (2010) have a different conclusion. Firms with an overall focus on product, process and organizational (technological and non-technological) innovations have a competitive advantage over non-innovative firms or those with partial innovation focus. LMT firms have five internal capabilities that impact their innovativeness. These include 'technological, marketing, integrative $R \& D$, cultural and emotional capabilities'. Organizational emotional capabilities related to individuals such as dynamics of encouragement and experiencing within a firm have a positive effect on product and process innovation while displaying freedom has a positive impact on process innovation (Akgun, Keskin \& Byrne, 2009). According to Huang and Chen (2010) firms can innovate better at a certain level of diversity in their technology base. However, beyond that limit technology diversity has a negative relationship with innovation. Innovation performance amongst firms with low $R \& D$ intensity is influenced more by production-based innovation factors and strategies that include gaining market access and maintaining customer connections (Hall \& Bagchi-Sen, 2007). The more a firm engages with the market and transforms accordingly the more likely it will innovate (Liao \& Rice, 2010). With regards to strategies, firms that have a diversification focus in terms of seeking collaborations with partner firms have better results from their collaborations (Lokshin, Hagedoorn, \& Letterie, 2011). Firms that better utilize sources of information present in their environment perform better on innovation due to the development of their technological innovation capabilities (Yam, Lo, Tang \& Laue, 2011). Firms with a market orientation perform well 
with respect to product innovation (Hernandez-Espallardo \& Delgado-Ballester, 2009).

Investigating the influence of firm-level decisions (internal versus external product and process technology development decisions) Swan and Allred (2003) found them to be associated negatively with differentiation strategy and positively with product dynamism. Also, acquiring product technologies from external sources was associated negatively with low cost goal and positively with increasing distance between primary marketing and R\&D operations. Talke, Salomo, and Rost (2010) find that diversity in the top management team of a firm has a strong positive influence on firm's strategic choices that lead to innovation.

Innovation is influenced by acquiring and utilizing knowledge generated within a firm as well as one gathered outside the firm boundaries such as about customers and competitors (Jimenez-Jimenez, Valle, \& Hernandez-Espallardo, 2008). Additionally, it is argued that instead of market orientation it is the organizational learning that can encourage innovation more. A similar study carried out two years earlier by Keskin (2006) investigates the relationships among market orientation, learning orientation and innovativeness. Results indicate that a firm's learning orientation influences its ability to innovate positively while learning orientation in turn is positively influenced by market orientation. Thus learning orientation serves as a mediator between a firm's market orientation and its innovativeness. An earlier work by Aldas-Manzano, Kuster, and Vila (2005) does not conform to Keskin's conclusions. Results suggest that market orientation is not statistically related to innovativeness. In line with a firm-specific focus on innovation determinants, certain studies propose models to enhance our understanding of these determinants. For example, Dobni (2008) uses literature review and mixed methods to present a seven-factors-model that influences an organization's innovation culture. These include innovation propensity, organizational constituency, organizational learning, creativity and empowerment, market orientation, value orientation and implementation context. However, the study only focuses on innovation in service-oriented firms. According to Morone and Testa (2008) firms remain competitive as a result of innovation by applying strategies such as specialization in quality products and creation of well-integrated social and institutional clusters. Innovation capacity (time to implement innovation), innovation specialists, innovative orientation of managers, documented planning for innovation, consultation with external organizations (non-firms) and collaboration with other firms and non-firms also influence innovation (De Jong \& Marsili, 2006).

In a study that uses a small group of firms, McAdam, Armstrong, and Kelly (1998) highlight the greater influence of organizational learning and human capital on innovation rather that a firm's total quality focus which is based more on mechanistic process based continuous improvement. Pullen, Weerd-Nederhoff, Groen, Song, 
and Fisscher (2009) investigate patterns of internal firm characteristics that lead to high innovation performance. Firms with high innovation performance as a result of incremental innovations have a similar 'configuration of internal organization'. This configuration focuses on an 'analyser or prospector' business strategy combined with the culture of 'adhocracy' (as opposed to hierarchy culture suggested in theory). Additionally, these firms were characterized by having no formal processes (as opposed to theory which suggests that best performing incremental SMEs have formal processes), a functional team structure and an internal climate that is entrepreneurial in nature. According to Choi, Lee, and Williams (2011) firms with foreign ownership tend to innovate more while firms with insider ownership (owners and managers are relatives or the same) perform poorly on innovation. However, the study is focused only on large firms.

Presenting a different perspective Buech, Michel, and Sonntag (2010) argue that employees can also contribute to firm innovation through their ideas and suggestion when their wellbeing is a priority for the firm. Amongst LMT firms working of teams to solve problems, intra-firm transfer of knowledge, more extensive and effective workflow and production scheduling contribute to improvements in manufacturing process innovations (Macher \& Mowery, 2003). Entrialgo, Fernandez, and Vazquez (2000) argue that the psychological characteristics of a manager can have effect on a firm innovativeness whereby entrepreneurial processes within the firm can play a mediating role. Consequently, it is suggested that a manager's psychological characteristics have little direct influence on a firm innovativeness. Woodcock, Mosey, and Wood (2000) find that while managers may strongly feel the need for new product development (NPD) they generally fail at implementation due to shifting of priorities arising from other short-term considerations. Data suggests little involvement of manufacturing managers within SMEs in the NPD process. A genuine lack of record keeping regarding NPD efforts results in shortage of information. This means firms are unable to streamline their NPD activities and improve performance by learning from past experience and knowledge.

\section{Findings from Literature}

The literature review for this paper reveals a total of 49 determinants of LT/ LMT innovation. 40 amongst these have been identified as firm-level determinants (Table 1 below).

However, it is pertinent to note that only 9 other determinants offer some perspective on the role of the firm's owner or top manager suggesting limited research so far. Table 1.3 offers a typology for these individuals based on a categorization across three levels derived from literature. These include (a) professional traits, (b) psychological 
Table 1: Firm-level Determinants of LT/LMT Innovation

\begin{tabular}{|c|c|}
\hline Process and product design & Creativity and empowerment \\
\hline Innovation budget & Innovation implementation context \\
\hline Advanced machinery and equipment & Top management support \\
\hline technological and market access & Learning orientation \\
\hline Integrative and internal $R \& D$ capabilities & Export intensity or orientation \\
\hline Customer-focus & Outsourcing R\&D \\
\hline Employee/worker skills and training & Marketing and organizational innovations \\
\hline $\begin{array}{l}\text { Innovation capacity (time to implement inno- } \\
\text { vation) }\end{array}$ & Design activities \\
\hline Innovation specialists & Employees' ideas and suggestion \\
\hline Documented planning for innovation & Level of diversity in technology base \\
\hline Collaboration with firms and non-firms & $\begin{array}{l}\text { Utilization of information sources present in the } \\
\text { environment }\end{array}$ \\
\hline $\begin{array}{l}\text { Internal vs. external technology development } \\
\text { decisions }\end{array}$ & Technological innovation capabilities. \\
\hline Organizational practices such as teamwork & Diversity in the top management team \\
\hline Intra-firm knowledge transfer & $\begin{array}{l}\text { Diversification focus in terms of seeking collabo- } \\
\text { rations with other partner firms }\end{array}$ \\
\hline Extensive workflows & $\begin{array}{l}\text { Engaging with market and transforming accord- } \\
\text { ingly }\end{array}$ \\
\hline Production scheduling & $\begin{array}{l}\text { Overall focus on product, process and organiza- } \\
\text { tional }\end{array}$ \\
\hline $\begin{array}{l}\text { Organizational culture including innovation } \\
\text { propensity }\end{array}$ & $\begin{array}{c}\text { innovation (technological and non-technological } \\
\text { innovation) }\end{array}$ \\
\hline Market-orientation & Partial innovation focus \\
\hline Value-orientation & Foreign ownership \\
\hline Organizational constituency & Insider ownership \\
\hline Organizational learning & \\
\hline
\end{tabular}

traits and (c) nature of stake in business

As Table 2 suggests, the exact dynamics and influence of these individual-level determinants on LT/LMT innovation remains vague. This is especially the case for professional traits and nature of business stake whereby it remains unclear how these two may influence LT/LMT innovation. It also remains unclear how the three categories of determinants would reveal themselves if LT/LMT innovation is being investigated within small firms. There is a need to capture the details within each 
Table 2: Owner or Manager Typology for LT/LMT Innovation in Firms

\begin{tabular}{|c|c|c|}
\hline Professional Traits & Psychological Traits & Nature of Stake in Business \\
\hline $\begin{array}{c}\text { Knowledge of innovation w.r.t. } \\
\text { business }\end{array}$ & Encouragement & $\begin{array}{c}\text { Shifting priorities with regards } \\
\text { to business }\end{array}$ \\
\hline & Freedom-orientation & \\
\hline & Experimenting \& playfulness & \\
\hline & Reconciliation & \\
\hline & Identification & \\
\hline & Risk-taking & \\
\hline & Proactive nature & \\
\hline
\end{tabular}

categorization level to formulate an in-depth understanding of the role of small firm owner and top manager with respect to LT/LMT innovation.

Moreover, from the perspective of paradigmatic influence and choice of research methods, the review of literature reveals that $67 \%$ studies are influenced by the positivistic approaches and rely on quantitative data, $20 \%$ have a phenomenological influence with qualitative data while a mere $3 \%$ use mixed methods. No empirically-based research studies were found that take influence from the critical realist view to understand LT/LMT innovation including the role of key individual. Figure 1 provides the results;

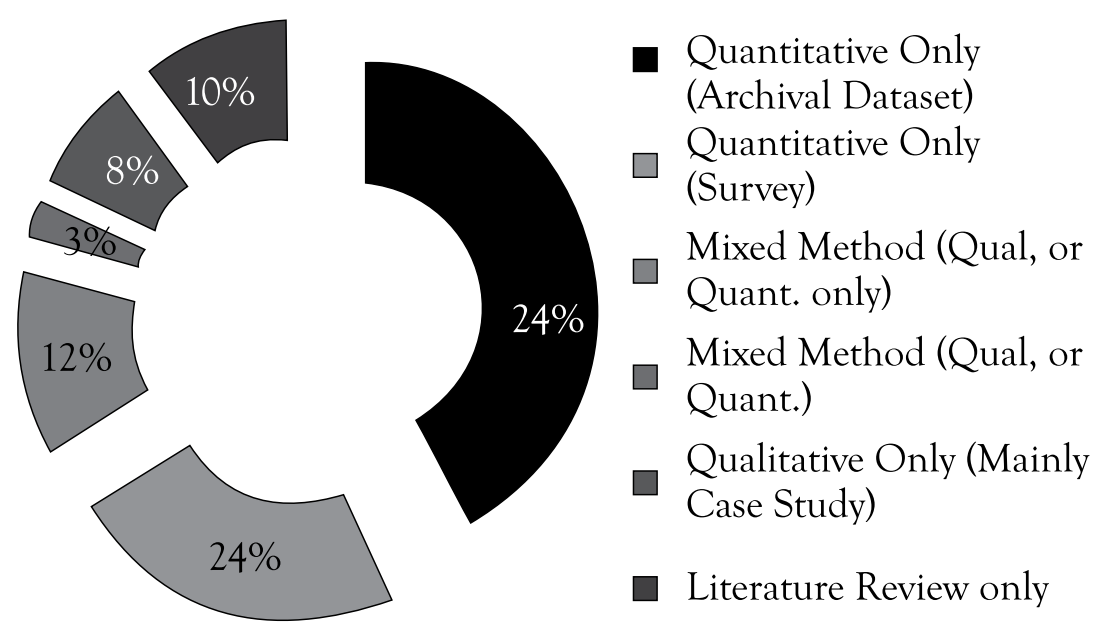

Figure 1: Methodology/Methods Applied by Researchers (Percentage of Articles) 
Consequently, there is a need to offer a much-needed critical realist perspective on the role of key individuals like owners and managers in terms of influencing LT/ LMT innovation within small firms.

\section{Methodology and Methods}

Paradigmatically this research is influenced by critical realism (not considered by previous studies) in order to develop a subjectivist-epistemological-transitive (Collier, 1994) construction of the reality that helps explain the influence of key individuals on LT innovation. The perspectives of Sayer $(2004 ; 2000 ; 1992)$ have been used for methodological application of critical realism to this research. Table 3 presents key components of critical realist thought in this regard;

Table 3: Adopted from Easton (2010) and Sayer $(2004 ; 1992)$

\begin{tabular}{|c|}
\hline Key Components of Critical Realist Thought \\
\hline $\begin{array}{c}\text { Objects/Entities Building blocks for critical realist explanations such as organizations, people, } \\
\text { resource }\end{array}$ \\
\hline $\begin{array}{c}\text { Events/Outcomes What critical realists investigate, they are external and visible outcomes of } \\
\text { behaviours of people, organizations, systems }\end{array}$ \\
\hline Causal powers The concept that objects/entities have causal powers that is they make things hap- \\
pen
\end{tabular}

Thus, deriving from the above table, occurrences of LT innovation have been conceptualized as events. The firm owners and top managers are being conceptualized as the objects or entities that have causal powers (elaborated in terms of individual-level determinants) and explained through causal mechanisms (ways in which objects cause events). The research relies on use of retroduction rather than applying inductive or deductive approaches. This in turn influences the methodology and methods applied 
in this research. Case study approach has been applied as it offers a context-rich understanding of a phenomenon and allows for use of mixed methods (Yin, 2003).

This research is empirically based in the marble industry of north-west Pakistan. Marble is a semi-precious stone found as a natural resource in different parts of the world and possesses commercial value in many markets of the world. Following factors influence the choice of marble industry for this research;

1. Zero $R \& D$ intensity amongst firms thus confirming the LT status of the industry

2. Presence of small firms only (mining and processing units) whereby the owner or manager has a key role to play with regards to LT innovation

Two cases have been selected whereby each case is a marble sector comprising of two types of small marble firms that is mining firms and processing firms. Selection of these cases is based on both sectors having the largest marble reserves and highest number of mining and processing firms in the region. Further, because this study applies 'replication logic' (literal replication) (Yin, 2003), the two cases have been selected for their similarities rather than differences.

1. Case 1 - PeMaS (Peshawar and Mohmand Agency Marble Sector)

2. Case 2 - BuMaS (Buner Marble Sector)

Applying a Two-Phase approach, mixed methods (also lacking in previous studies) have been used to collect data including semi-structured in-depth interviews, structured interviews and questionnaires. Table 4 provides the distribution of respondents amongst the two cases (marble sectors) and the relevant data collection tools used.

The semi-structured interviews with two marble sector experts who had in-depth experience of working with various government and international agencies for uplift of the industry were used to identify key stakeholders for further data collection. It was found that innovation within the marble industry in north-west Pakistan is primarily being influenced by owners and managers of mining and processing firms, suppliers or middlemen who deal with equipments, machineries and technologies being employed by mining and processing firms and representatives of relevant government departments who influence the regulatory and operational environment of these firms. Consequently, Phase-I interviews have been conducted using purposive sampling - heterogeneous or maximum variation to gain an in-depth and multi-dimensional perspective (Saunders, Lewis, \& Thornhill., 2006) while Phase-II interviews and questionnaires were conducted using purposive sampling - homogeneous in order 
to gather more consolidated data. Phase-I while exploring various dimensions of LT innovation and identifying issues and perspectives, informs the ensuing structured interview and questionnaire in Phase-II resulting in triangulated data. Data has been analyzed using Miles and Huberman (1994) relying on descriptive and pattern coding, memos, and matrices

Table 4: Two-Phased Data Collection

\begin{tabular}{|c|c|c|c|}
\hline PHASE & TOOL & NUMBER & RESPONDENTS \\
\hline I & $\begin{array}{l}\text { Semi-structured In- } \\
\text { depth Interview }\end{array}$ & $\begin{array}{c}12 \text { (6 PeMaS + } \\
6 \text { BuMaS) }\end{array}$ & 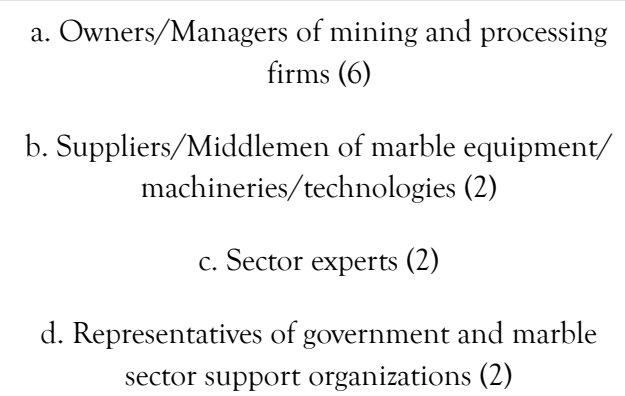 \\
\hline \multirow[t]{2}{*}{ II } & $\begin{array}{l}\text { Structured Inter- } \\
\text { view }\end{array}$ & $\begin{array}{l}18 \text { (10 PeMaS } \\
+8 \text { BuMaS) }\end{array}$ & Owners/Managers of mining firm \\
\hline & Questionnaire & $\begin{array}{l}70 \text { (35 PeMaS } \\
+35 \mathrm{BuMaS})\end{array}$ & Owners/Managers of processing firm \\
\hline
\end{tabular}

\section{Findings and Discussions}

The marble industry in north-west Pakistan is characterized by two subsectors, mining and processing within the two selected cases PeMaS and BuMaS. Very few instances of incremental LT innovation in terms of products and processes are prevalent. For mining subsector three key objects that are three types of individuals along with their distinct roles have been identified. They include mine owner (MO), mine manager (MM) and supervisor also called 'munshi' in the local language. For processing subsector, three variants of owner-manager arrangement or ownership structure have been found. These are;

1. Variant 1 - one owner-manager (O-M)

2. Variant 2 - one owner and one manager (O\&M)

3. Variant 3 - one owner plus one manager $(\mathrm{O}+\mathrm{M})$

In variant 1 , a single individual owns as well as manages or operates the processing factory. In variant 2 , the owner and manager are two separate individuals with distinctly 
different roles. In variant 3 , the owner and manager while being separate individuals, manage the business together. These three variants of small firm ownership are an interesting discovery hitherto not found within previous works, e.g. Choi et al. (2011) who investigate ownership structure of large firms only, Becheikh et al. (2006) who focus only on foreign ownership, and Gudmundson, Tower, and Hartman (2003) who identify only one variant of ownership structure in small firms similar to variant 3. It is pertinent to note that the above mentioned ownership structures define the diverse nature of business stakes for these individuals discussed later.

\subsection{Understanding Objects or Entities: Roles of Key Individuals in the Marble Sector}

Analysis of data reveals three categories of the roles of key individuals;

1. Professional traits

2. Nature of business stake

3. Psychological traits

Table 5 presents a role-ordered matrix (Miles \& Huberman, 1994, pp. 122-126) taking influence from the typology (Table 2) developed earlier through the literature review. The matrix provides ordered information regarding roles for the different variants of ownership in mining and processing firms of the two marble sectors.

Table 5 offers a unique perspective on objects within the marble sector from a critical realist perspective. As mentioned at the start of this section, marble mining and processing firms demonstrate very limited product and process innovations that are primarily incremental in nature. Lack of innovation is the norm whereby the same products such as tiles, slabs, decorative items are being produced applying the same production technologies including blasting, driller, excavator, loader, vertical/ horizontal cutter, gang saw, polisher and others since the last 30 to 35 years. However, from a critical realist perspective the event or outcome that is the limited occurrence of LT innovation can be explained by a variety of underlying mechanisms including those related to key individuals that is the focus of this research. These mechanisms are the result of the causal powers or determinants of objects. Table 5 not only provides information regarding the roles of individuals but also how these different roles influence LT innovation amongst marble firms. It also reveals that the objects within the marble sector are structured rather than unstructured thereby allowing us a view that is in sharp contrast to quantitative paradigm that focuses on variables as characteristics of the objects rather than the objects themselves (Easton, 2010; Sayer 1992) 
Table 5: Role-Ordered Matrix - Roles of Individuals within PeMaS and BuMaS

\begin{tabular}{|c|c|c|c|}
\hline Individual & Professional Traits & $\begin{array}{c}\text { Nature of Business } \\
\text { Stake }\end{array}$ & Psychological Traits \\
\hline Mine Owner (MO) & $\begin{array}{l}\text { - Better off financially } \\
\text { - Basic / higher edu- } \\
\text { cation } \\
\text { - Sound understand- } \\
\text { ing of official or legal } \\
\text { procedures } \\
\text { - Strong contacts with } \\
\text { government authori- } \\
\text { ties including DGMM } \\
\text { - Able to acquire min- } \\
\text { ing license } \\
\text { - Not a resident of } \\
\text { mining area }\end{array}$ & $\begin{array}{l}\text { - Direct stake in receiv- } \\
\text { ing lease payments } \\
\text { - Indirect stake in costs } \\
\text { incurred as a result of } \\
\text { operations } \\
\text { - No direct stake in } \\
\text { product quality and } \\
\text { sales/profits } \\
\text { - Owner of reserves, } \\
\text { unclear stake in their } \\
\text { wastage } \\
\text { - No direct stake in } \\
\text { terms of investment of } \\
\text { resources }\end{array}$ & $\begin{array}{l}\text { IM - Not relevant due } \\
\text { to nature of stake } \\
\text { EA - Inclined towards } \\
\text { understanding the le- } \\
\text { gal/official procedures, } \\
\text { maintaining personal } \\
\text { contacts with officials } \\
\text { RTB - Geared towards } \\
\text { financial investment } \\
\text { for obtaining license } \\
\text { AII - Present but un- } \\
\text { applied A1? and A2? }\end{array}$ \\
\hline Mine Manager (MM) & $\begin{array}{l}\text { - Struggling to cope } \\
\text { with finances } \\
\text { - No / basic education } \\
\text { - Does not deal with } \\
\text { license acquisition } \\
\text { - Strong personal con- } \\
\text { tacts with population } \\
\text { of mining area } \\
\text { - Does not own mining } \\
\text { license } \\
\text { - Resident of local } \\
\text { mining area and/or } \\
\text { member of local tribe }\end{array}$ & $\begin{array}{l}\text { - Direct stake in mak- } \\
\text { ing lease payments } \\
\text { - Direct stake in costs } \\
\text { incurred as a result of } \\
\text { operations } \\
\text { - Direct stake in pro- } \\
\text { ducing more but not } \\
\text { product quality } \\
\text { - Reserves not owned, } \\
\text { no stake in their } \\
\text { wastage } \\
\text { - Direct stake in terms } \\
\text { of investment in } \\
\text { resources }\end{array}$ & $\begin{array}{l}\text { IM - Not present due } \\
\text { to nature of stake } \\
\text { EA - Inclined towards } \\
\text { maintaining trust } \\
\text { of MO and mutual } \\
\text { understanding } \\
\text { RTB - Dealing with } \\
\text { uncertain law \& order, } \\
\text { inconsistent revenues } \\
\text { due to uneven sale/ } \\
\text { demand trends } \\
\text { AII - Unapplied, } \\
\text { influenced more by } \\
\text { external factors } \\
\text { A1? and A2? }\end{array}$ \\
\hline Supervisor/ 'Munshi' & NK & $\begin{array}{l}\text { - Satisfy MO in terms } \\
\text { of trust } \\
\text { - Draw monthly salary }\end{array}$ & $\begin{array}{l}\mathrm{IM}-\sim \text { EA }-\sim \sim \\
\mathrm{RTB}-\sim \text { AII }-\sim \sim\end{array}$ \\
\hline
\end{tabular}




\begin{tabular}{|c|c|c|c|}
\hline $\begin{array}{l}\text { Variant } 1 \text { One Own- } \\
\text { er-Manager (O-M) of } \\
\text { Proc. Unit }\end{array}$ & $\begin{array}{l}\text { - Financial strength } \\
\text { - C? } \\
\text { - No / basic / higher } \\
\text { education } \\
\text { - Sound business } \\
\text { knowledge, high } \\
\text { involvement in oper- } \\
\text { ations } \\
\text { - Direct influence on } \\
\text { workers' productivity } \\
\text { - Strong and direct } \\
\text { influence on types of } \\
\text { products, processes, } \\
\text { marketing, organiza- } \\
\text { tional structure }\end{array}$ & $\begin{array}{l}\text { - Direct stake in reve- } \\
\text { nues and profits gener- } \\
\text { ated from operations } \\
\text { - Direct stake in } \\
\text { minimizing wastage to } \\
\text { reduce costs } \\
\text { - Direct stake in prod- } \\
\text { uct quality leading to } \\
\text { more sales } \\
\text { - Direct stake in terms } \\
\text { of investment in } \\
\text { resources }\end{array}$ & $\begin{array}{c}\text { IM - T? } \\
\text { EA - cost reduction, } \\
\text { less focus on quality } \\
\text { RTB - Investment in } \\
\text { resources, dealing with } \\
\text { inconsistent revenues } \\
\text { due to uneven sale/ } \\
\text { demand trends } \\
\text { AII - Strong, demon- } \\
\text { strated by some but } \\
\text { not all } \\
\text { A1? and A2? }\end{array}$ \\
\hline $\begin{array}{l}\text { Variant } 2 \text { One Owner } \\
\text { and One Manager } \\
(\mathrm{O \& M}) \text { of Proc. Unit }\end{array}$ & $\begin{array}{c}\text { - O better off finan- } \\
\text { cially } \\
\text { - No/basic/higher } \\
\text { education } \\
\text { - M sound business } \\
\text { knowledge, high } \\
\text { involvement in oper- } \\
\text { ations } \\
\text { - M direct influence on } \\
\text { workers' productivity } \\
\text { - O \& M unclear } \\
\text { influence on types of } \\
\text { products, processes, } \\
\text { marketing, organiza- } \\
\text { tional structure }\end{array}$ & $\begin{array}{l}\text { - O direct stake in } \\
\text { return on investment } \\
\text { - O direct stake in costs } \\
\text { incurred on operations } \\
\text { - M indirect stake in } \\
\text { return on investment } \\
\text { - M indirect stake } \\
\text { in costs incurred on } \\
\text { operations } \\
\text { - M direct stake in } \\
\text { maintaining O's trust } \\
\text { - M direct stake in } \\
\text { salary }\end{array}$ & $\begin{array}{c}\text { IM - T? for both O } \\
\text { \& M } \\
\text { EA - O inclined } \\
\text { towards financial } \\
\text { returns, } \mathrm{M} \text { - inclined } \\
\text { towards maintaining } \\
\text { trust of } \mathrm{O} \\
\text { RTB - O financial } \\
\text { investment, M - } \\
\text { AII - Diluted as a re- } \\
\text { sult of O \& M having } \\
\text { different roles } \\
\text { A1? and A2? }\end{array}$ \\
\hline
\end{tabular}




\begin{tabular}{|c|c|c|c|}
\hline $\begin{array}{l}\text { Variant } 3 \text { One Owner } \\
+ \text { One Manager } \\
(\mathrm{O}+\mathrm{M}) \text { of Proc. Unit }\end{array}$ & $\begin{array}{c}\text { - O better off finan- } \\
\text { cially } \\
\text { - No/basic/higher } \\
\text { education } \\
\text { - O+M sound business } \\
\text { knowledge, high } \\
\text { involvement in oper- } \\
\text { ations } \\
\text { - O+M direct influence } \\
\text { on workers' produc- } \\
\text { tivity } \\
\text { - O+M strong in- } \\
\text { fluence on types of } \\
\text { products, processes, } \\
\text { marketing, organiza- } \\
\text { tional structure }\end{array}$ & $\begin{array}{l}\text { - O direct stake in } \\
\text { return on investment } \\
\text { - O direct stake in costs } \\
\text { incurred on operations } \\
\text { - M indirect stake in } \\
\text { return on investment } \\
\text { - M indirect stake } \\
\text { in costs incurred on } \\
\text { operations } \\
\text { - M direct stake in } \\
\text { maintaining O's trust } \\
\text { - M direct stake in } \\
\text { salary }\end{array}$ & $\begin{array}{c}\text { IM - T? for both O } \\
+\mathrm{M} \\
\text { EA - O inclined } \\
\text { towards financial } \\
\text { returns, } \mathrm{M} \text { - inclined } \\
\text { towards maintaining } \\
\text { trust of O } \\
\text { RTB - O financial } \\
\text { investment, M - } \\
\text { AII - Strong as a result } \\
\text { of combined influence } \\
\text { of O+M, demonstrated } \\
\text { by some not all A1? } \\
\text { and A2? }\end{array}$ \\
\hline
\end{tabular}

$\mathrm{IM}=$ Innovation Mindset; $\quad$ EA = Entrepreneurial Approach; RTB=RiskTaking Behaviour; $\quad$ NK $=$ Not Known

AII = Ability to Influence Innovation; C $=$ Unclear Evidence on Characteristic; $\mathrm{T} ?=$ Inconclusive Evidence on Trait

$\sim \sim$ = Irrelevant Trait; A1? = Unclear evidence on 'I-want-to-improve-but-amhelpless' Attitude;

A2? = Unclear evidence on 'I-cannot-improve-someone-else-will-do-it' Attitude; _ $=$ Sub-sector role boundary;

— $=$ Complete separation $\mathrm{b} / \mathrm{w}$ roles within sub-sector; $\_=$Within sub-sector role boundary

\subsection{Understanding Mechanisms and Causal Powers: Individuals' Influence on LT Innovation in Marble Mining Firm}

As discussed during the review of literature on critical realism, the paradigm argues that objects have causal powers. Focusing on these causal powers means inquiring about what makes the objects cause events. Therefore, the limited or no occurrence of the event of LT innovation within the marble mining sub-sector can be traced to a number of causal powers. A major one amongst these is the non-alignment of objects that is the owner and manager's business interests or stakes. While the former has a 
prime stake in ensuring that the lease payments on the marble mine to the manager are received regularly, the latter is concerned more about minimizing operational costs. The owner has no direct stake in improving product quality or increasing sales and profits. The manager on the other hand is under pressure to produce more quantity without any regard for the wastage of marble resources resulting from indiscriminate blasting. He does not own the raw marble anyway and is not concerned with extracting it efficiently. Moreover, the owner does not have any direct investment in the mining business in terms of equipment, machinery and other resources. His only investment is payment to the government's Directorate General Mines and Minerals (DGMM) for acquiring the mining license for a given location. On the other hand, the manager has invested in the mining business in terms of equipments and pays salaries to the workers. Since he is making a fixed payment per month or per unit of excavated marble stone to the owner, his approach is towards maximizing production regardless of wastage resulting from blasting that leaves stones with cracks and irregular shapes/ sizes while a lot of smaller stone becomes commercially useless. The supervisor or 'munshi' represents the interest of the owner by keeping track of how much stone is being extracted per day and per month. These findings present a very interesting perspective on critical realism whereby one entity or object is influencing the other entity through its causal powers resulting in non-occurrence of the event, a key concern for critical realists (Bhaskar, 1991). Moreover, the divergent stakes of owners, managers and supervisors or 'munshis' resulting in limited events of LT innovation offer a unique perspective compared to some of the earlier works such as Choi et al. (2011) and Gudmundson et al. (2003). These studies suggest that large and small firms perform poorly on innovation due to insider ownership whereby stakes of the owner and manager converge.

Further mechanisms and causal powers that underlie limited occurrences of LT innovation have been revealed through the interaction of objects. For instance, in terms of individual traits, differences between the mine owner and manager exist as well. The owner does not have an innovation mindset simply because he does not consider it to be relevant or in line with his business stake. This is in line with De Jong and Marsili (2006) and Woodcock et al. (2000) who point out firms lacking managers with an innovation orientation and shifting priorities do not perform well on LT innovation. Analysis of the two cases reveals that the manager does not have the innovation mind-set especially with respect to the products because of his priority for cost reduction. The owner's entrepreneurial approach is mainly concerned with establishing and maintaining good contacts and relationships with government officials having the authority to issue, renew and cancel mining licenses. On the contrary, the manager is more concerned with ensuring the trust of mine owner in order to keep his mining business operational. A fundamental characteristic of innovation is 
that it entails risk-taking behaviour. However, the owner's only risk is investment in the business through purchase of mining license while the manager's risk revolves around dealing with the uncertain law and order situation in the mining areas and inconsistency of business revenues due to uneven demand and sales trends. While both key individuals have the ability to influence innovation within the mining firm, the owner does not seem to be applying it due to no direct stake or benefit derived from innovation. On the other hand, the manager does not appear to exercise that influence because of greater concerns external to his business. These include maintaining good relationships with the local tribes or villagers, maintaining a good working relation with the owner based on trust and keeping operational costs as low as possible to ensure minimum level of profit margins. The diverging interests of two key individuals in the mining firms with no priority for innovation or product/process improvement and lack of encouragement, experiencing and freedom leads to lack of LT innovation (Akgun et al., 2009) in the mining subsectors of PeMaS and BuMaS.

\subsection{Understanding Mechanisms and Causal Powers: Individuals' Influence on LT Innovation in Marble Processing Firm}

The analysis of data for this study reveals a relatively more complex nature of the mechanisms and causal powers within the marble processing sub-sector. Three variants of owner-manager arrangement have been identified in Section 6 above. Consequently, the key individuals' influence on LT innovation also varies for the specific variant present in the processing firm suggesting the existence of specific causal powers. Variant 1 (O-M) turns out to possess the strongest possible causal powers that can influence LT innovation. This is in line with Chang (2003), Chang and Hong (2000) and Jensen and Meckling (1976) who argue that firms with insider ownership whereby the owner and manager are the same or own the business jointly can result in improved innovation performance of the business. However, Choi et al. (2011) found the opposite in the case of large firms. This contrasting view yet again brings to the forefront the longstanding differences between how ownership structures and business stakes can have completely different influences on performance of large vs. small firms. Offering explanations our study of the underlying mechanisms in the marble processing firms suggests that the owner who also manages the processing business has a direct stake in all aspects of the business. Not only is he inclined to minimize wastage of stone during different processing activities but he is also more determined to improve quality of the product to ensure greater sales and profitability. Moreover, because of absolute authority within the firm, the owner-manager directly influences types of products produced, the production processes used to manufacture these products, decisions on which markets and customers to target and what kind of organizational structure is implemented (including number of workers, supervisor, if 
any, and assignment of tasks, responsibilities and authority). As far as the individual traits are concerned data reveals inconclusive evidence for innovation mind-set for variant 1 . During interviews and questionnaires, some respondents in the variant 1 category demonstrated a strong innovation mind-set with willingness to take risk and invest in better technologies. They also had a strong ability to influence innovation by being authoritative and having a long-term vision for their business. On the contrary, other respondents in variant 1 did not have any innovation mind-set, were unwilling to take risk or improve products/processes. Their ability to influence innovation was also limited or non-existent. However, both types of processing firms with contrasting psychological traits of variant 1 did not differ on innovation performance which is contrary to some of the previous work (De Jong \& Marsili 2006; Entrialgo, 2000). This leads to the conclusion that a deeper set of inner personality traits that is further underlying causal mechanisms are at play when it comes to the influence of O-M on LT innovation. Further research is needed to unravel these inner traits of the owner-manager in order to understand why these differences in psychological traits do not reveal differences in LT innovation performance of the firms.

Variant $2(\mathrm{O} \& M)$ was found to demonstrate the weakest causal powers in terms of influence on LT innovation in line with previous work (Choi et al., 2011; Becheikh et al., 2006; Woodcock 2000). The underlying mechanisms are somewhat similar to the owner-manager arrangement identified for mining units. While the owner of the processing unit is better off financially, he does not have a direct involvement in day-to-day operations (activities performed by the manager). The manager has more technical knowledge about products and processes and a direct influence on workers' productivity. On the other hand, the owner has a stake in returns on his investment and cost reduction to maximize profits. Since the manager is paid a monthly salary only that is a direct stake he has an indirect stake in cost reduction and profit maximization as this ensures his own employment in the long-run. Similar to variant 1 there is unclear evidence for innovation mind-sets of $O \& M$. For some processing firms it is there while for others it is not found. However, one important finding is that the owner can have a greater influence on innovation because of investments in better technologies and marketing decisions. However, this influence subsides considerably if the manager does not reciprocate owner's mind-set with improving operational activities that lead to product/process innovation. In term of entrepreneurial approach, owner is concerned more with return on investment while the manager's priority is to maintain the owner's trust in him. The main reason for weak influence of $O \& M$ on LT innovation is found to be the diluted influence of owner and manager due to a lack of complementarities of their roles.

Variant $3(\mathrm{O}+\mathrm{M})$ is found to have influence on $\mathrm{LT}$ innovation that is weaker than 
variant 1 but stronger than variant 2 . This suggests the existence of causal powers that demonstrate a mixture of characteristics. The main reason identified for greater influence than variant 2 is that both the owner and manager are involved in day-to-day operations whereby the manager's main role is that of supervising and interacting with workers. However, both individuals are involved in decisions regarding products and production processes. Also, both have a sound knowledge of products and processes. These results align with Akgun et al. (2009) who argue that the more the owner and manager jointly demonstrate involvement in business and decision making the more likely is the occurrence of innovation. On the other hand, the main reason identified for the weaker influence on LT innovation than variant 1 is the differences in nature of stake. While the owner has a direct stake in ensuring returns on investment, the manager's stake in this regard is indirect as he is more concerned about the salary and maintaining trust of the owner.

\section{Conclusion and Directions for Future Research}

This research offers a much needed and unique understanding of critical realism as argued by Easton (2010), Sayer (2004), Bhaskar (1998; 1997), Collier (1994) and many scholars who want to shed light on this often-ignored research paradigm through of its fundamental tenets including events, objects, mechanisms and causal powers. It offers an understanding of these theoretical concepts through empirical evidence drawn from north-west Pakistan's marble sector. It links up this evidence with another ignored area within the realm of innovation research that is low-technology innovation whereby the role of individuals that is the firm owners and managers has not been investigated in detail. It explains the complex nature of the influence of objects that is key individuals within small firms on events that is occurrence of LT innovation across three key aspects (a) professional traits, (b) psychological traits and (c) nature of business stake. In order to explain this influence mechanisms that refer to the ways in which individuals influence innovation, and causal powers, that include innovation determinants, have been elucidated. Findings reveal that amongst the mining firms the owner and manager have clearly drawn divergent causal powers influencing their involvement in the mining business. This results in a lack of focus on improving marble products and production processes during the mining phase. The finding is in line with previous work that suggests that the owner and manager's shifting priorities and lack of innovation orientation influences the lack of LT innovation inside firms. For processing firms, three variants of the owner-manager arrangement have been identified. Variant 1 has the strongest causal power to influence LT innovation as one individual performs the role of firm's owner as well as its manager and has a clear and strong influence on the firm's actions and activities including innovation. However, unclear evidence on innovation mind-set and ability to influence innovation 
emerges for variants 2 and 3. This suggests that deeper underlying mechanisms and causal powers in terms of roles of individuals are at play. Consequently, it is recommended that future research work should focus on further investigating the influence of objects on events such as LT innovation especially in light of the different roles or mechanisms (variant 2 and 3 for this study) that exist within small firms.

\section{References}

Akgun, A. E., Keskin, H., \& Byrne, J. (2009). Organizational emotional capability, product and process innovation, and firm performance: An empirical analysis. Journal of Engineering and Technology Management, 26(3), 103-130.

Aldas-Manzano, J., Kuster, I., \& Vila, N. (2005). Market orientation and innovation: An inter-relationship analysis. European Journal of Innovation Management, 8(4), 437-452.

Atkinson, P., \& Hammersley, M. (1994). Ethnography and participant observation. In N. K. Denzin \& Y. S. Lincoln (Eds.), Handbook of qualitative research. (pp. 171-198). Thousand Oaks, CA: Sage.

Ayer, A. J. (1959). Logical positivism. New York, NY: The Free Press.

Becheikh, N., Landry, R., \& Amara, N. (2006). Lessons from innovation empirical studies in the manufacturing sector: A systematic review of the literature from 1993-2003, Technovation, 26, 644-664.

Bessant, J. (2008). Dealing with discontinuous innovation: The European experience, International Journal of Technology Management, 42(1/2), 36-50.

Bhaskar, R. (1989a). The possibility of naturalism. Brighton: Harvester.

Bhaskar, R. (1989b). Reclaiming reality: A critical introduction to contemporary philosophy. London: Verso.

Bhaskar, R. (1991). Philosophy and the idea of freedom. Oxford: Blackwell.

Bhaskar, R. (1997). A realist theory of science. New York, NY: Verso.

Bhaskar, R. (1998). The possibility of naturalism: A philosophical critique of the contemporary human sciences. London: Routledge.

Boer, H., \& Gertsen, F. (2003). From continuous improvement to continuous innovation: A retro perspective., International Journal of Technology Management, 26(8), 805-827.

Boer, H., \& Gieskes, J. F. B. (2001). Editorial of the special issue. International Journal of Technology Management, 22(4), 338-345.

Buech, V. I. D., Michel, A., \& Sonntag, K. (2010). Suggestion systems in organizations: What motivates employees to submit suggestions? European Journal of Innovation Management, 13(4), 507-525.

Chang, S. J. (2003). Ownership structure, expropriation and performance of group-affiliated companies in Korea. Academy of Management Journal, 46(2), 238-253. 
Chang, S. J., \& Hong, J. (2000). Economic performance of group-affiliated companies in Korea: Intragroup resource sharing and internal business transactions. Academy of Management Journal, 43(1), 429-448.

Choi, S. B., Lee, S. H., \& Williams, C. (2011). Ownership and firm innovation in a transition economy: Evidence from China. Research Policy, 40(2), 441-452.

Collier, A. (1994). Critical realism: An introduction to Roy Bhaskar's philosophy. London: Verso.

Collis, J., \& Hussey, R. (2003). Business research: A practical guide for undergraduate and postgraduate students. Basingstoke: Palgrave Macmillan.

Corso, M., Martini, A., \& Balocco, R. (2008). Organising for continuous innovation: The community of practice approach. International Journal of Technology Management, 44(3-4), 441-460.

De Jong, J., \& Marsili, O. (2006). The fruit flies of innovations: A taxonomy of innovative small firms. Research Policy, 35(2), 213-229.

Dobni, C. B. (2008). Measuring innovation culture in organizations: The development of a generalized innovation culture construct using exploratory factor analysis. European Journal of Innovation Management, 11(4), 539-559.

Dunk, A. S. (2007). Innovation budget pressure, quality of IS information, and departmental performance. The British Accounting Review, 39(2), 115-124.

Easterby-Smith, M., Thorpe, R., \& Lowe, A. (2002). Management research: An introduction. London: Sage.

Easton, G. (2010). Critical realism in case study research. Industrial Marketing Management, 39, 118-128.

Edquist, C. (2005). Systems of innovation: Perspectives and challenges. In J. Fagerberg, D. C. Mowery \& R. R. Nelson (Eds.), The Oxford handbook of innovation. (pp. 118-141). New York, NY: Oxford University Press.

Entrialgo, M., Fernandez, E., \& Vazquez, C. J. (2000). Psychological characteristics and process: The role of entrepreneurship in Spanish SMEs. European Journal of Innovation Management, 3(3), 137-149.

Evangelista, R., \& Vezzani, A. (2010). The economic impact of technological and organizational innovations: A firm-level analysis. Research Policy, 39(2), 1253-1263.

Fairclough, N. (2005). Discourse analysis in organization studies: The case for critical realism. Organization Studies, 26(6), 915-939.

Filippetti, A. (2011). Innovation modes and design as a source of innovation: A firm-level analysis. European Journal of Innovation Management, 14(1), 5-26.

Glaser, B., \& Strauss, A. (1977). The discovery of grounded theory: Strategies for qualitative research. Chicago: Aldine.

Guba, E., \& Lincoln, Y. (1989). Fourth generation evaluation. Newbury Park, CA: Sage. 
Guba, E., \& Lincoln, Y. (1994). Competing paradigms in qualitative research. In N. K. Denzin \& Y. S. Lincoln (Eds.), Handbook of qualitative research. Thousand Oaks, CA: Sage.

Gudmundson, D., Tower, C. B., Hartman, E. A. (2003). Innovation in small businesses: Culture and ownership structure do matter. Journal of Developmental Entrepreneurship 8(1), 1-17

Hall, L. A., \& Bagchi-Sen, S. (2007). An analysis of firm-level innovation strategies in the US biotechnology industry. Technovation, 27(1-2), 4-14.

Hernandez-Espallardo, M., \& Delgado-Ballester, E. (2009). Product innovation in small manufacturers, market orientation and the industry's five competitive forces: Empirical evidence from Spain. European Journal of Innovation Management, 12(4), 470-491.

Hirsch-Kreinsen, H., (2008a). Low-tech innovations. Industry and Innovation, 15(3), 23-37.

Hirsch-Kreinsen, H. (2008b). Low-technology: A forgotten sector in innovation policy. Journal of Technology Management and Innovation, 3(3), 11-20.

Hirsch-Kreinsen, H., \& Jacobson, D. (2008). Innovation in low-tech firms and industries. Cheltenham: Edward Elgar Publishing.

Howe, K. (1988). Against the quantitative-qualitative incompatibility thesis or dogmas die hard. Educational Researcher, 17(8), 10-16.

Huang, Y., \& Chen, C. (2010). The impact of technological diversity and organizational slack on innovation. Technovation, 30, 420-428.

Jensen, M., \& Meckling, W. (1976). Theory of the firm: Managerial behaviour, agency costs, and ownership structure. Journal of Financial Economics, 3(4), 305-360.

Jimenez-Jimenez, D., Valle, R. S., \& Hernandez-Espallardo, M. (2008). Fostering innovation: The role of market orientation and organizational learning. European Journal of Innovation Management, 11(3), 389-412.

Johnson, P., \& Duberley, J. (2000). Understanding management research: An introduction to epistemology. London: Sage.

Keskin, H. (2006). Market orientation, learning orientation, and innovation capabilities in SMEs: An extended model. European Journal of Innovation Management, 9(4), 396-417.

Kirner, E., Kinkel, S., \& Jaeger, A. (2009). Innovation paths and innovation performance of low-technology firms - an empirical analysis of German industry. Research Policy, 38(3), 447-458.

Kuhn, T. (1970). The structure of scientific revolutions. Chicago: Chicago University Press.

Lawson, T. (1997). Economics of reality. London: Routledge.

Liao, T., \& Rice, J. (2010). Innovation investments, market engagement and financial performance: A study among Australian manufacturing SMEs. Research Policy, 39(1), 117-125. 
Lincoln, Y., \& Guba, E. (1985), Naturalistic inquiry. Newbury Park, CA: Sage.

Lokshin, B., Hagedoorn, J., \& Letterie, W. (2011). The bumpy road of technology partnerships: Understanding causes and consequences of partnership mal-functioning. Research Policy, 40, 297-308.

Macher, J. T., \& Mowery, D. C. (2003). Managing learning by doing: An empirical study in semiconductor manufacturing. Journal of Product Innovation Management, 20(5), 391-410.

Martini, A., Laugen, B. T., Gastaldi, L., \& Corso, M. (2013). Continuous innovation: Towards a paradoxical, ambidextrous combination of exploration and exploitation. International Journal of Technology Management, 61(1), 1-22.

McAdam, R., Armstrong, G., \& Kelly, B. (1998). Investigation of the relationship between total quality and innovation: A research study involving small organisations. European Journal of Innovation Management, 1(3), 139-147.

Miles, M. B., \& Huberman, M. (1994). Qualitative data analysis: An expanded sourcebook. London: Sage.

Morone, P., \& Testa, G. (2008). Firms growth, size and innovation: An investigation into the Italian manufacturing sector. Economics of Innovation and New Technology, 17(4), 311-329.

Mothe, C., \& Thi, T. U. N. (2010). The link between non-technological innovations and technological innovation. European Journal of Innovation Management, 13(3), 313-332.

Nagel, T. (1986). The view from nowhere. New York, NY: Oxford University Press.

Nouman, M., \& Warren, L. (2010). Low-technology innovations within sectoral system: Reflections and manifestations. Paper presented at the British Academy of Management Conference Management Research in a Changing Climate in Sheffield United Kingdom from September 14 to 16 2010. Retrieved November 102016 from https://www.bam.ac.uk/conference-2010

O'regan, N., \& Kling, G. (2011). Technology outsourcing in manufacturing small- and medium-sized firms: Another competitive resource? RED Management, 41(1), 92-105.

Pullen, A., Weerd-Nederhoff, P., Groen, A., Song, M., \& Fisscher, O. (2009). Successful patterns of internal SME characteristics leading to high overall innovation performance. Creativity and Innovation Management, 18(3), 209-223.

Raymond, L., \& St-Pierre, J. (2010). R\&D as a determinant of innovation in manufacturing SMEs: An attempt at empirical clarification. Technovation, 30, 48-56.

Saunders, M., Lewis, P., \& Thornhill, A. (2006). Research methods for business students. Harlow: Financial Times Prentice Hall.

Sayer, A. (1992). Method in social science: A realist approach. London: Routledge.

Sayer, A. (2000). Realism and social science. London: Sage.

Sayer, A. (2004). Why critical realism. In S. Fleetwood \& S. Ackroyd (Eds.), Critical realist applications in 
organisation and management studies. (pp. 66-89). London: Routledge.

Schwandt, T. (2000). Three epistemological stances for qualitative inquiry: Interpretivism, hermeneutics, and social constructionism. In N. Denzin \& Y. Lincoln (Eds.), Handbook of qualitative research. (pp. 78-119). Thousand Oaks, CA: Sage.

Souitaris, V. (1999). Research on the determinants of technological innovation: A contingency approach. International Journal of Innovation Management, 3, 287-306.

Souitaris, V. (2002). Technological trajectories as moderators of firm-level determinants of innovation. Research Policy, 31(6), 877-898.

Swan, K. S., \& Allred, B. B. (2003). A product and process model of the technology-sourcing decision. Journal of Product Innovation Management, 20(6), 485-496.

Talke, K., Salomo, S., \& Rost, K. (2010). How top management team diversity affects innovativeness and performance via the strategic choice to focus on innovation fields. Research Policy, 39(4), 907-918.

Vega-Jurado, J., Gutierrez-Gracia, A., Fernandez-De-Lucio, I., \& Manjarres-Henriquez, L. (2008). The effect of external and internal factors on firm's product innovation. Research Policy, 37(4), 616-632.

Von Tunzelmann, N., \& Acha, V. (2005). Innovation in 'low-tech' industries. In J. Fagerberg, D. C. Mowery \& R. R. Nelson (Eds.), The Oxford handbook of innovation. (pp. 407-432). Oxford: Oxford University Press.

Woodcock, D., Mosey, S. P., \& Wood, T. B. W. (2000). New product development in British SMEs. European Journal of Innovation Management, 3(4), 212-222.

Yam, R. C. M., Lo, W., Tang, E. P. Y., \& Lau, A. K. W. (2011). Analysis of sources of innovation, technological innovation capabilities and performance: An empirical study of Hong Kong manufacturing industries. Research Policy, 40(4), 391-402.

Yin, R. K. (2003). Case study research: Design and methods. Thousand Oaks, CA: Sage. 